\title{
Jens Mungard \\ - Strandtidslen er min blomst
}

\author{
Af Mogens RostgaArd Nissen
}

I februar 1940 døde den frisiske digter Jens Emil Mungard i koncentrationslejren Sachsenhausen. Det var afslutningen på et brydsomt liv. Han blev født i Keitum på Sild som søn af den kendte landmand og sprogforsker, Nann Mungard, og de to havde et kompliceret forhold til hinanden. Jens Mungards gård blev brændt af efter, at hans far i 1920 havde deltaget meget aktivt i afstemningskampen for at få øens befolkning til at stemme dansk. Det så de tysksindede frisere på Sild ikke på med milde øjne. Efter den nazistiske magtovertagelse i 1933 kom han hurtigt på kant med regimet og begyndte at skrive kritiske digte om styret. Samtidig skrev Jens Mungard mere end 800 poetiske digte på den frisiske dialekt, Sölring, og han regnes af flere som den vigtigste nordfrisiske digter.

\section{Indledning}

»Den frisiske digter og sprogforsker Jens Mungard fra Keitum/Sild bragte med sin sprogforskning det tyske sprogs enhed i fare. Derfor måtte han i KZ-lejr. Den 15. februar 1940 døde han dér efter en svær lungebetændelse. Kommandanten nægtede at indlægge den meget syge på infirmeriet, og sådan udåndede Mungard på en stråsæk i barak 27. «1

Med disse ord beskrev en anden kz-fange, Heinrich Lienau fra Flensborg, hvordan den frisiske digter Jens Emil Mungard ${ }^{2}$ døde i februar 1940 i koncentrationslejren Sachsenhausen. Ganske vist var datoen forkert, idet Mungard døde den 13. februar, men der er god grund til at tro Lienaus skildring af omstændighederne. Da han døde, havde Mungard været fange i lejren knap et år, men på denne korte tid blev han så afkræftet, at han døde af det. ${ }^{3}$ Det var afslutningen på et liv, der på mange måder var brydsomt og ulykkeligt - familiemæssigt, socialt og politisk. Men Jens Mungard regnes også af flere som den største blandt de nordfrisiske digtere, og der er således noteret i Deutsche Philologie im Aufriss fra 1960: »Den betydeligste nordfrisiske 
digter i vore dage er landmanden fra øen Sild, Jens Mungard, Keitum. [...] Ja, hans dybsindige og ordmaleriske værker åbner porten på vid gab fra den ellers tematisk set ofte lidt snævre dialekt-forskning. « ${ }^{4}$

Fokus i denne artikel er rettet mod Jens Mungards liv, mens digtene fylder mindre. Det skyldes, at hans liv rummede en lang række interessante aspekter, selv om det også er en meget trist historie. Ud fra hans historie kan man samtidig få et indtryk af nogle af de problemer, nordfriserne havde i første halvdel af det 20. århundrede mellem det danske og det tyske. Desuden er det en forudsætning for at kunne forstå indholdet af hans digte, at man har et kendskab til hans liv.

Min interesse for Jens Mungard er blevet skabt i forbindelse med, at Dansk Centralbibliotek for Sydslesvig i samarbejde med dr. Martin Sadek opstillede en Mungard-udstilling i foråret 2013. I takt med at Marie Tångeberg oversatte mange af Mungards digte til dansk, blev min nysgerrighed vakt. Hvorfor valgte en hedebonde fra Sild at skrive disse smukke digte om $\sin \varnothing$, og hvordan kunne det gå til, at han endte sine dage i en kz-lejr? Da det samtidig viste sig, at vi i Arkivet ved Dansk Centralbibliotek for Sydslesvig opbevarer en stor del af hans efterladte arkivalier, lå det lige for at skrive en artikel om Jens Mungard. En artikel, der også rummer meget om hans far, Nann Mungard, fordi de tos liv var vævet tæt sammen.

\section{Forskning og kilder}

Der er ikke skrevet ret meget om Jens Mungard, og indtil nu er det stort set udelukkende om de digte, han skrev. Det eneste, der er skrevet på dansk om ham, er en kort artikel fra 1985 i Slesvigland i forbindelse med 100-året for hans fødsel. Der er skrevet lidt mere om ham på tysk og især på frisisk. Hans Hoeg fik i 1982 overdraget rettighederne til Jens Mungards arkivalier af datteren, Elisabeth Mungard, og han gjorde i løbet af 1980'erne en meget stor indsats for at indsamle materiale om Nann og Jens Mungard. I 1985 udgav Hans Hoeg Jens Mungard. Fuar di min hart heer slain, der var den første bog på frisisk med nogle af Mungards digte samt kopier af breve til vestfrisiske kontakter og til hans kontakt, Hermann Schmidt, hvor især brevet dateret 31. juli 1938 er vigtigt. I 1995 fulgte Hoeg op med Ströntistel an Dünemruusen. Das Lyrische Werk, der indeholder mere end 800 digte skrevet af Jens Mungard. I 1989 udgav han Nann Mungards selvbiografi, Der Friese Jan, hvor man får et indblik i farens liv - naturligvis 
set med farens briller. Lederen af Nordfriisk Instituut i Bredsted, dr. Thomas Steensen, har flere gange skrevet om Mungard-familien, herunder nogle korte biografier i Das Neue Sylt Lexikon fra 2007 og i Die friesische Bewegung in Nordfriesland im 19. und 20. Jahrhundert (18791945), men noget samlet Mungard-værk er det ikke blevet til. Senest har Steensen og Ingo Laabs skrevet en kort artikel om Mungard i indledningen til Jens Mungard. Gedichte - Dechtings. Endelig har den tidligere leder af Nordfriesischen Wörterbuchstelle, Ommo Wilts, skrevet to korte, men særdeles interessante artikler. Han formår med stor tydelighed at dokumentere, at Jens Mungard ikke blot var en vigtig nordfrisisk lyriker - han blev også en meget skarp politisk digter. $^{5}$

Hans Hoeg gjorde som nævnt i løbet af 1980'erne en meget stor indsats for at indhente kilder om både Nann og Jens Mungard, og det er i Hoegs arkiv, at hovedparten af de primære kilder til denne artikel er hentet. ${ }^{6}$ Heri er der kopier af en række forskellige juridiske dokumenter fra tyske myndigheder vedrørende Jens Mungard, herunder anholdelseserklæringer fra 1936 og officielle breve fra Sachsenhausen i forbindelse med Mungards død. Desuden er der en brevveksling mellem Hoeg og Elisabeth Mungard, der var Nann Mungards barnebarn og Jens Mungards datter. Hun har den 25. januar 1983 skrevet et 17 sider langt brev til Hoeg, hvor hun kommer med en lang række indgående oplysninger om familien Mungard, ligesom hun har skrevet et lidt kortere - og mindre indgående - brev til Thomas Steensen den 19. januar 1983. Brevene er selvsagt vanskelige kilder, idet de er skrevet meget lang tid efter Jens Mungards død. Samtidig er datteren andenhåndskilde til mange oplysninger, og hun har desuden en klar tendens til fordel for sin far, mens hun beskriver sin bedstefar og mor, Anna Maria, langt mere kritisk. Om sit forhold til sine forældre skrev hun blandt andet: »Jeg har altid haft ondt af Anna, og jeg har også her stillet mig på hendes side, men mit hjerte tilhører Jens." Hun skrev også i brevet, at baggrunden for hendes beretning var, at Sven Simon i 1980 havde udgivet Sylt, hvor bedstefaren blev beskrevet som den store mand. Denne udlægning var hun træt af, og da Jens Mungard ikke selv kunne forsvare sig, følte hun sig forpligtet til at gøre det. I brevet til Thomas Steensen fulgte hun op med at forklare: "Jeg havde ganske vist en far og en mor, men ingen forældre«, hvilket må tages som et udtryk for, at hun mente, at hun havde haft en stor distance til begge sine forældre. ${ }^{7}$ Af dette brev 
fremgår også, at hun havde et dårligt forhold til sin yngre søster, Nani Söderberg, som hun mente stod bag udlægningen i Sylt. Indholdet af begge disse breve bærer præg af, at selv om hun forsøgte at betragte det Mungardske hjem med en vis analytisk distance, så lykkedes det ikke at give et neutralt billede af forholdene i hendes barndomshjem. Det trækker væsentligt op på troværdigheden af Elisabeth Mungards udlægning, at hun bad Hans Hoeg og Thomas Steensen om at undlade at bruge de informationer, hun gav dem om forholdene i det Mungardske hjem.

Hoeg har desuden indsamlet hovedparten af indholdet til både Nann og Jens Mungards arkiver, blandt andet udkastet til Der Friese $\mathrm{Jan}^{8}$ og et udateret og ufuldstændigt udkast til Jens Mungards erindringer. ${ }^{9}$ I Der Friese Jan forholder Nann Mungard sig indgående til sine oplevelser som styrmand og kaptajn i Kina og Fjernøsten i årene fra omkring 1870, til han vendte tilbage til Sild i 1883. Desuden kommer han med nogle grundige beskrivelser af sine udadvendte aktiviteter efter, han var kommet tilbage til Sild, især vedrørende arbejdet med at fremme det frisiske sprog. Omvendt har han ikke skrevet ret meget om sin egen familie, og derfor er det næsten udelukkende del tre, der omfatter tiden omkring afstemningen i 1920, der benyttes i artiklen.

\section{Jens Mungards familiebaggrund}

Når man vil skrive om Jens Mungard, er det nødvendigt at gøre en del ud af hans familiemæssige baggrund og særligt give en ret udførlig beskrivelse af forholdet til faren, Nann Mungard, og til hustruen Anna Maria Mungard. Han havde mildt sagt et kompliceret forhold til sin far, hvilket også fik stor betydning for forholdet til hustruen. Dette aspekt er næsten udeladt i de fremstillinger, der hidtil er skrevet om Jens Mungard, hvor forholdet til hustruen og børnene stort set er fraværende.

Jens Mungard blev født den 9. februar 1885 i Keitum på Sild. Hans far var landmanden og sprogforskeren Nann Mungard, mens hans mor, Elisabeth, var født Schwennen og kom fra en kaptajnsfamilie i Keitum. Mungard-slægten kom oprindeligt fra Sønderjylland, og efternavnet stammer fra gården Munkgaard ved Rejsby. ${ }^{10}$ Det var oldefaren Niels Kaspersen Munkgaard, der flyttede til Sild, hvor han ernærede sig som landmand og fisker, og hvor han giftede sig med 


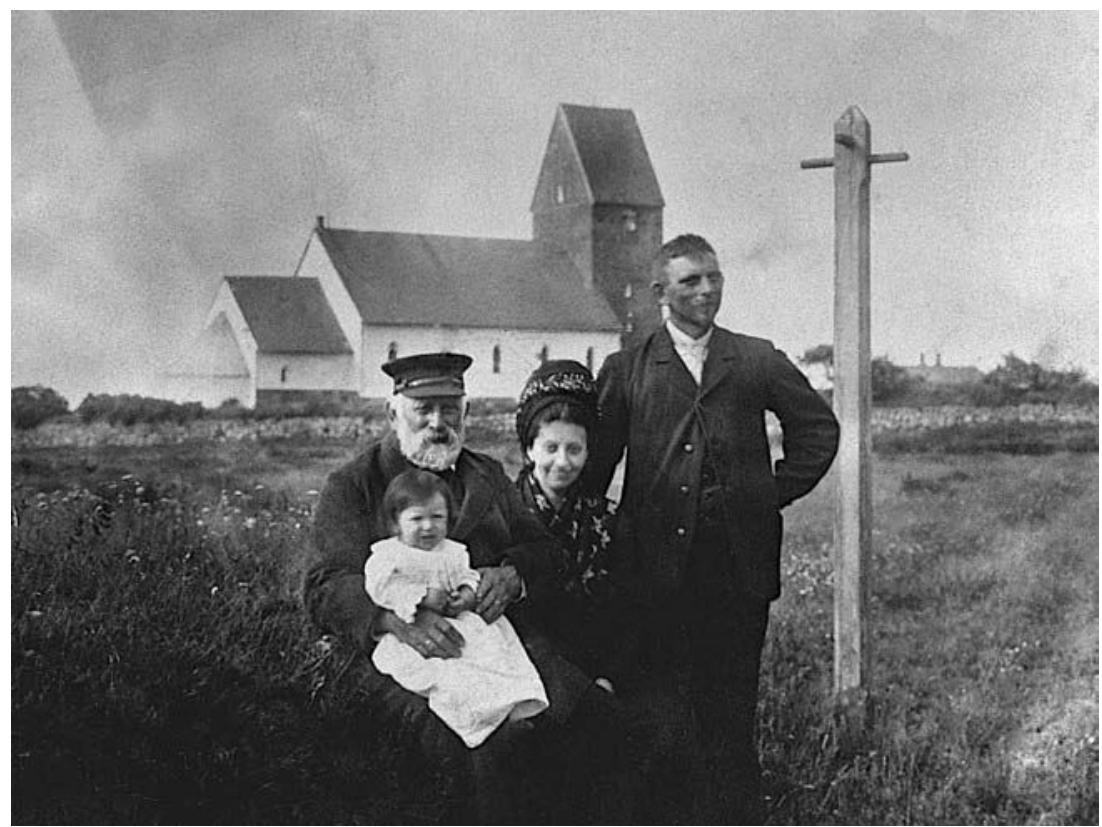

Billede fra 1912 af Nann Mungard med barnebarnet Elisabeth på skødet. Anna Maria sidder ved siden af, og Jens Mungard står op. I baggrunden ses Keitum kirke. Foto: Arkivet ved Dansk Centralbibliotek for Sydslesvig (Hans Hoegs privatarkiv).

en pige fra øen. Bedstefaren Claas Niels Mungaard ${ }^{11}$ var landmand og skomager i Keitum, og han giftede sig med en dansk pige fra Gallehus ved Tønder. ${ }^{12}$ Skal man tro Jens Mungards erindringer, var bedstefaren en dygtig hesteopdrætter, og da den danske konge besøgte øen i begyndelsen af 1840'erne, var det bedstefaren, der kørte kongen rundt $\mathrm{i}$ hestevogn. ${ }^{13}$

Der hersker næppe tvivl om, at Jens Mungards bedsteforældre var dansksindede og tro mod den danske konge, idet Nann Mungard skriver noget tilsvarende i sine erindringer om sine forældre. ${ }^{14}$ Der er også meget, der tyder på, at der blev talt dansk - eller i hvert fald sønderjysk - i hjemmet hos Claas Niels Mungard, og at det således har været et af de sprog, Nann Mungard talte i sin barndom. Hoeg anfører dog i forordet til Der Friese Jan, at Nanns modersmål var frisisk, men at han også talte dansk og tysk samt sønderjysk og plattysk. Senere lærte han at tale engelsk, kinesisk, japansk og malaysisk. ${ }^{15}$

At Nann Mungards forfædre var dansksindede sønderjyder, kan 
være en forklaring på, hvorfor han gik så stærkt ind i kampen for at få befolkningen på Sild og i Sydslesvig til at stemme dansk i 1920. Men der hersker ikke tvivl om, at han først og fremmest opfattede sig selv som friser.

Nann Mungard blev født i 1849 i Keitum, og som barn begyndte han at sejle i skoleferierne. Senere påmønstrede han som 14-årig i Hamborg og sejlede primært mellem Europa og Fjernøsten. I 1870 tog han styrmandseksamen, og frem til 1883 sejlede han som styrmand og kaptajn mellem Japan, Kina og USA. Ud over en tysk skibsførereksamen havde han desuden en engelsk, en japansk og en kinesisk. Jens Mungard anfører, at Nann havde fungeret som sikkerhedsofficer for den kinesiske vicekonge, Li-Tung-Chang. Det er uvist, hvad der nærmere ligger i det, men Elisabeth Mungard har i sit brev til Hans Hoeg fulgt op på det og udtrykker en overbevisning om, at Nann havde været en slags spion. ${ }^{16}$ Hun hentyder formentlig til den kinesiske militærleder og statsmand, Li Hung-chang, der i 1870'erne havde stor indflydelse på kinesisk udenrigspolitik, og han stod bag en gradvis tilnærmelse mod Vesten, især til Storbritannien. ${ }^{17}$ Dermed antyder hun, at Nann Mungard i årene, inden han kom tilbage til Sild, kan have været meget tæt forbundet med den britisk-orienterede kinesiske udenrigsminister. Selv skriver Nann i sin selvbiografi, at han gjorde tjeneste på forskellige kinesiske skibe, der blandt andet sejlede med kinesiske soldater. ${ }^{18}$

Det var således en mand, der havde set og oplevet meget, som vendte tilbage til Sild i oktober 1883. Han var næsten 35 år gammel, og kort efter blev han gift med Elisabeth Emilie Schwennen fra Keitum. Hun var ud af en velhavende kaptajnsfamilie, og hendes far, kaptajn Jens Erk Schwennen, havde haft stor indvirkning på, at Nann overhovedet kom ud at sejle. Ifølge Jens Mungards datter, Elisabeth, medbragte hendes bedstemor, Elisabeth, en betydelig medgift, hvilket Nann ikke skrev noget om i erindringerne. Året efter brylluppet blev Jens Mungard født, og i 1886 kom den næste søn, Claas, til verden. Kort efter blev Elisabeth syg, og hun døde i 1889. Elisabeths ni år ældre søster, Louise, havde allerede under sygdommen taget sig af husholdningen og de to små drenge, og i 1890 blev hun og Nann Mungard gift. Igen blev der betalt en stor medgift, og det var en vigtig grund til, at Nann kunne udvide bedriften, opdyrke ny hedejord og udvikle sit landbrug. ${ }^{19}$

Jens Mungard gik i landsbyskolen i Keitum i perioden 1891-1900. 
Skolen havde tre klasser, men han fortæller selv, at læreren, Meinert Dirksen, havde stået for en langt bedre undervisning end den foreskrevne, så niveauet var på højde med undervisningen i byskolerne. ${ }^{20}$ Han antyder også, at han havde været en mønsterelev, som læreren havde givet endnu mere undervisning end de øvrige elever, og at han på den måde gik ud af skolen med særligt gode kundskaber.

Som dreng ønskede Jens at komme ud at sejle, men Nann modsatte sig ønsket, fordi Jens skulle overtage gården. Derfor blev Jens sendt til Bredsted på landbrugsskole, inden han skulle aftjene værnepligt. Han meldte sig frivilligt til feltartilleriet i Rendsborg, fordi - som han skrev - »sundhedstilstanden hos mine forældre var ikke god, så jeg havde en interesse i hurtigst muligt at få afsluttet min militærtjeneste«. Samtidig kunne han bruge sin viden om heste, idet han kom til at passe kompagniets heste. Det var et tydeligt tegn på, at Jens Mungard ikke fik de samme muligheder som sin far for at komme ud at sejle, fordi Nann Mungard ønskede, at sønnen kom hjem og overtog gården på Sild. ${ }^{21}$

Jens kom tilbage til gården i 1906, og overtog den i 1909. Forinden var plejemoren, Louise, død, og hun havde ifølge Jens havde været en god og kærlig mor for ham og broren Claas. Da Jens tog over, var han 25 år, mens Nann var 61. Sidstnævnte havde allerede i nogle år været meget optaget af at skrive en frisisk ordbog - der udkom i 1909 - og han var med til at etablere foreningen »Di Foriining fuar Söl'ring Spraak en Wiis« i 1900. Jens noterede lakonisk i udkastet til sine erindringer om Nanns arbejde med ordbogen efter, at Jens havde overtaget gården: »Nu havde han mulighed for fuldstændigt at hellige sig den sag.« Det virker som en noget bittersød kommentar fra en mand, der netop havde overtaget gården efter sin far, som herefter kunne forfølge sine egne interesser. Med til historien hører, at Jens allerede på dette tidspunkt var begyndt at skrive digte på frisisk, og at han sammen med sin far var i tæt kontakt med vestfrisiske ledere og sprogforskere fra Holland.

Da Jens overtog gården, var den på omkring 24 hektar. Prisen var 24.000 mark, og af dem havde han selv 9.000, mens han måtte låne resten. $^{22} \mathrm{I}$ de følgende år frem til udbruddet af 1 . Verdenskrig blev bedriften udvidet betydeligt og var da på omkring 40 hektar. Det virker, som om det var vigtigt for Jens Mungard at forklare, at han faktisk havde været en dygtig og driftig landmand, og at det var ydre omstændigheder, der senere fik det til at gå dårligt, jf. nedenfor. 


\section{Ægteskabet med Anna Maria}

Jens Mungard blev gift med Anna Maria Andresen den 29. april 1910. Hun kom fra Før, og ifølge Hoeg var hun datter af en kroejer, mens Elisabeth Mungard har anført, at morfaren, Lorenz August Andresen, var kaptajn og en bekendt af Nann Mungard. ${ }^{23}$ Jens Mungard har berettet påfaldende lidt om ægteskabet. Faktisk har han blot noteret »maj 1910«, som tidspunktet for brylluppet, og at »af dette ægteskab er der kommet fire børn «. Det er ydermere kun det førstefødte barn, datteren Elisabeth, han har skrevet navnet på, mens han kun har noteret fødselstidspunktet for de følgende tre børn, men uden at angive deres navne. Med risiko for at overfortolke kan dette i hvert fald antyde, at Jens Mungard ikke havde noget nært forhold til de tre yngste børn. Elisabeth blev født i november 1911, mens der i september 1913 blev født tvillinger, Helene og Lorenz, inden den yngste datter, Nani, blev født i juni 1919. Om ægteskabet har Hoeg meget kort noteret, at det ikke var særlig lykkeligt, og at hustruen havde givet Jens fire børn. ${ }^{24}$ Selv har Jens Mungard overhovedet ikke skrevet om sin hustru i udkastet til sine erindringer, hvilket kraftigt antyder, at forholdet til hende havde været dårligt. Det skal tages i betragtning, at erindringerne er skrevet på et tidspunkt i 1930'erne, og dermed sandsynligvis efter, at han blev skilt fra Anna Maria i 1934.

Datteren Elisabeth havde en noget mere kontroversiel udlægning af forholdene under dette ægteskab. ${ }^{25}$ For det første mente hun ikke, at Jens overhovedet var interesseret $i$ at blive gift, men at det var Nann, der efter hustruen Louises død i januar 1909 insisterede på, at der manglede en kvinde på gården i Keitum. Nann vidste, at kaptajn Andresen på Før havde fire døtre, og han fik aftalt, at Anna Maria skulle giftes med Jens. Først havde han dog, ifølge Elisabeth, sat trumf på ved at meddele: »Hvis ikke du gifter dig med hende, så gør jeg.« Det skulle Anna Marias forældre angiveligt have været indforstået med, men Jens valgte altså til sidst at følge sin fars ønske. Det næste problem i forbindelse med ægteskabet var ifølge Elisabeth, at Anna Maria var gravid, da brylluppet fandt sted. Historien melder ikke noget om, hvem faren til barnet var, men det var i hvert fald ikke Jens. Anna Maria fik i efteråret 1910 en dødfødt søn, inden Elisabeth blev født et års tid senere som det første af de fire levende børn.

At ægteskabet ikke var lykkeligt, var ifølge Elisabeth noget af en underdrivelse. Selv om det først var i 1934, at forældrene blev skilt, 


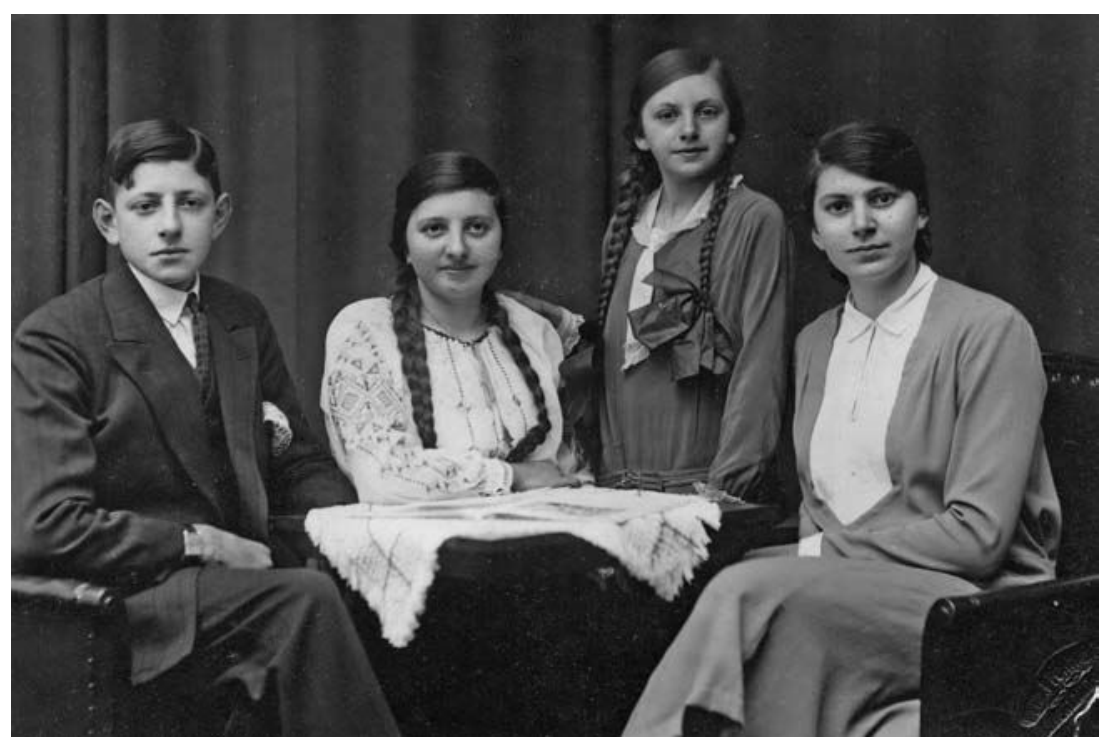

Fotografi fra omkring 1930 af Jens Mungards børn. Fra venstre er det Lorenz, Helene, Nani og Elisabeth. Jens Mungard havde tilsyneladende ikke noget særligt nært forhold til tre af sine børn. Kun den ældste Elisabeth bevarede op gennem 1930'erne en tæt kontakt til sin far, og det var da også hende, der var enearving. Foto: Arkivet ved Dansk Centralbibliotek for Sydslesvig (Hans Hoegs privatarkiv).

havde de to aldrig noget nært forhold, og hovedårsagen til det var ifølge barnebarnet, at Nann Mungard boede hos dem. Hun udtrykte det sådan: »I dag tror jeg, at Jens og Anna med tiden ville være rykket sammen - hvis ikke Nann havde levet i huset.« Hun udtrykte meget tydeligt, at det formentlig var Nann, der var far til de tre yngste børn: »Jens tilvejebragte kun én datter. Nann gjorde ham til det, man vel i dag vil kalde en taber. [...] Han ville sikkert vise, at han kunne bedre og se da, der kom to. Der blev ikke taget hensyn til Anna - hvorfor også - arven skulle sikres. « Hun beskriver, hvordan Nann og Anna Maria boede sammen i stueetagen, mens Jens boede for sig selv på første sal. Indtil Nann forlod Sild i 1921, blev Jens skubbet ud, og han udviklede »elefanthud over for sin såkaldte familie«, som Elisabeth udtrykte det. Man skal naturligvis tage det forbehold, at Elisabeth helt tydeligt tog sin fars parti, mens hun var stærkt kritisk i forhold til bedstefaren, hvorimod hun havde lidt mere forstående holdning til sin mor. Men der tegner sig dog et billede af, at Nann forpestede 
livet for Jens. Måske netop derfor skrev Jens mange digte i denne periode. Det er en vigtig pointe i Elisabeths udlægning af forholdene, at der ikke var tale om en banal romantisk historie, hvor bedstefaren og svigerdatteren faldt for hinanden. Nann krævede en mandlig arving, der kunne overtage familiegården i Keitum, og da Jens ikke kunne klare det, valgte han selv at tage over. ${ }^{26}$

Når man læser de korte biografier om Jens Mungard er det kendetegnende, at han beskrives som en stor digter og en dårlig landmand, der ikke havde forstand på penge. I modsætning hertil skildres Nann som en mand, der både var en rigtig dygtig landmand og en virkelig pioner inden for frisisk sprogforskning. Nann formåede i løbet af 25 år at skabe Silds største og bedste gård samtidig med, at han var involveret $\mathrm{i}$ en lang række udadvendte aktiviteter på øen sammen med frisiske organisationer i Nord- og Vestfrisland. Svend Overlade har således citeret Carl Meyer - der både var Nanns ven og udgiver for at have skrevet om Nann: "Aften efter aften sad han over sin ordsamling, selv om aftentimerne kom efter en hård og anstrengende arbejdsdag. Det var sådan, at når han under arbejdet kom i tanke om et vigtigt ord, så forlod han plov og hest på marken og ilede hjem for at skrive ordet ned.« ${ }^{27}$ Det var netop denne udlægning af bedstefaren som den store mand og faren som den sværmeriske digter, Elisabeth ville gøre op med. Som beskrevet opfattede hun i høj grad sin bedstefar som en mand, der overlod det sure arbejde på gården til sin søn, for at han selv kunne forfølge sine interesser vedrørende det frisiske sprog. Og det var en mand, der opførte sig som en slags gøg, der under det gratis ophold hos Jens og Anna Maria stødte den noget verdensfjerne søn ud. Det er dog vigtigt at slå fast, at Elisabeth i sine breve i januar 1983 til Hans Hoeg og Thomas Steensen bad dem om at undlade at skrive noget om forholdene hos Mungard-familien og udelukkende beskrive deres indsats som frisisk sprogforsker og frisisk digter. Omvendt står det også klart, at hun var træt af det offentlige billede af »den store mands store søn«, der især blev malet i Sven Simons Sylt fra $1980 .^{28}$

Elisabeth Mungard var dog enig i udlægningen af, at hendes far havde været en dårlig landmand, der ikke havde haft forstand på penge. Netop denne opfattelse forsøgte han selv at gøre op med i udkastet til sine erindringer. ${ }^{29}$ Han skrev, at han efter overtagelsen af gården i 1909 brugte hele sin energi på bedriften og på familien. På kort tid blev gården udvidet fra 25 til 40 hektar, kvægbestanden blev 


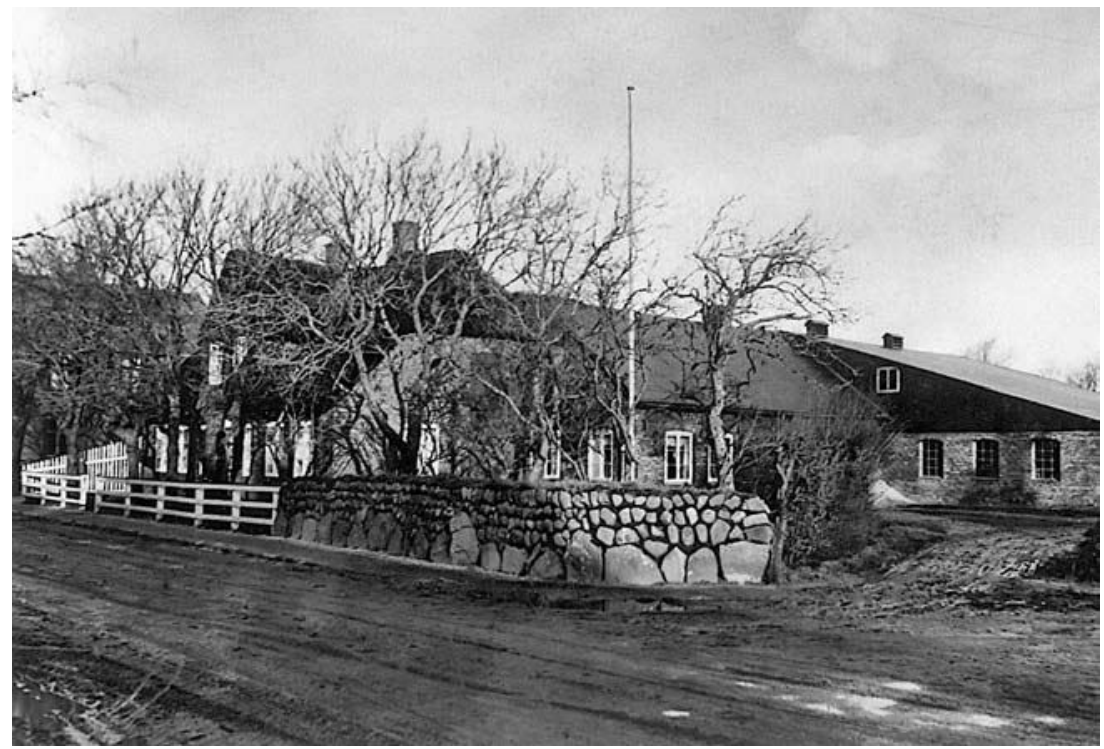

Fotografi af Mungards ejendom Weidemannsweg 1, Keitum. Foto: Arkivet ved Dansk Centralbibliotek for Sydslesvig (Hans Hoegs privatarkiv).

»væsentligt forøget «, og der blev anskaffet nye maskiner, blandt andet »den første tærskemaskine og den første slåmaskine med dybdeskær, den første petroleumsmotor til de faste maskiner, og da gården lå meget højt, blev der anskaffet en vindmotor til at hente vand. Økonomisk gik det virkelig godt og så kom krigen«. Hvis man tror på hans egen udlægning, var han altså en meget driftig og dygtig landmand, men så kom krigen og ødelagde en masse. Gården blev »et storartet rekvireringssted for staten«, og gården leverede en syvendedel af Keitums forbrug af mælk, selv om gården kun udgjorde omkring fem procent af landsbyens samlede areal. I løbet af krigen faldt dyreholdet på gården betragteligt, og da krigen var ovre i november 1918, var der et stort behov for at genopbygge bedriften. Han beskrev, hvordan antallet af hornkvæg blev forøget fra seks til 28 i perioden mellem november 1918 og januar 1921, mens antallet af heste i samme periode steg fra en til tre, ligesom bestandene af får og svin blev forøget kraftigt. Jens Mungard havde således formået at genskabe bedriften, da gården brændte ned den 15. januar 1921 som følge af en påsat brand. ${ }^{30}$ 


\section{Folkeafstemning og brand}

Der er gode grunde til at tro, at der var en direkte sammenhæng mellem folkeafstemningen den 14. marts 1920 og nedbrændingen af Jens Mungards gård ti måneder senere. Om branden og opklaringsarbejdet skrev Jens Mungard selv: »Undersøgelsen af brandårsagen blev efter min mening gennemført meget mangelfuldt. Jeg og mange andre var af den mening, at der blev hemmeligholdt noget. Man fik det indtryk, at myndighederne undlod at blotlægge de respektive brandstiftere og deres bagmænd. « 31

Jens Mungard angav en meget direkte sammenhæng mellem afstemning og brandattentat. Selv om han på brandtidspunktet havde været eneejer af gården i mere end ti år, var dette ikke kendt af andre end den nærmeste familie. Derfor regnede han det for sandsynligt, at brandstifterne ønskede at ramme Nann Mungard, der formodedes at være ejeren. ${ }^{32}$

Under afstemningskampen havde Nann Mungard været meget aktiv for at få befolkningen til at stemme dansk. ${ }^{33}$ Han opfattede først og fremmest sig selv som friser, men han mente, at friserne ville opnå størst selvstændighed, hvis man kom under dansk styre. Derfor gik han sammen med den i eftertiden bedre kendte Cornelius Petersen ind i kampen for at få friserne til at stemme dansk. ${ }^{34}$ Han skrev et læserbrev i juli 1919 i Sylter Zeitung og underskrev den som »tidligere kaptajn i den britiske merkantile marine«. Det blev ikke taget nådigt op af de tysksindede frisere, og den 25. juli modtog han et postkort adresseret til »Højforræder og spion Nann Mungard i Keitum«, som var underskrevet af en fiktiv professor dr. Müller. ${ }^{35}$ I de følgende måneder gik bølgerne højt, og Nann skrev en række læserbreve, der løbende blev besvaret af forskellige tysksindede frisere. En væsentlig del af denne debat drejede sig om historiske spørgsmål, hvor især fortolkningen af Uwe Jens Lornsen kom til at stå i centrum. ${ }^{36}$ Alt i alt var kampen mellem Nann Mungard og Cornelius Petersen på den ene side og en række tysksindede frisere på den anden side en tydelig illustration af, hvor splittet friserne var i forbindelse med folkeafstemningen i 1920. Ifølge Jens Mungard oplevede Nann også at se en dukke af sig selv blive brændt af den 21. februar 1920, hvilket igen viser, at afstemningskampen for alvor satte sindene i kog på øen. Men selve afstemningen gav en forholdsvis klar afgørelse på Sild, idet mere end tre ud af fire stemte tysk. 
Som nævnt blev Jens Mungards gård brændt af ti måneder senere, og han troede som beskrevet selv, at det hang sammen med folkeafstemningen. Jens var tilsyneladende ikke særligt engageret i valgkampen, og der er ingen antydninger af, at han udtalte sig offentligt om, at man skulle stemme dansk. Der er dog næppe tvivl om, at han som sin far foretrak et dansk styre, og der er endnu mindre tvivl om, at naboerne regnede ham som dansksindet. Nann var mere klar i mælet end sin søn, da han udpegede en sandsynlig brandstifter. I sine erindringer skrev han: »Det er bevidnet og dermed står det fast, at mølleren, Paul Hermann Peters i Keitum, har sagt; Det har den gamle landsforræder og spion kun godt af [...] Dagen efter branden har Jan [det vil sige Nann, MRN] selv set, at møller Peters sammen med sin hustru både om formiddagen og om eftermiddagen har spadseret ved brandstedet og er gennem længere tid set ved de rygende ruiner.« Derefter gik Nann over til mølleren og spurgte, om han kendte noget til brandstiftelsen, hvilket blev benægtet. ${ }^{37}$ Uden at det nævnes i erindringerne, virker det overvejende sandsynligt, at Nann også opfattede mølleren Peters som den dr. Müller, der havde sendt trusselskortet i sommeren 1919.

Efter branden valgte Nann Mungard at flytte fra Sild, og han bosatte sig i Møgeltønder. Her havde han fortsat tæt kontakt med Cornelius Petersen og boede en tid i dennes hus. De tabte begge i forbindelse med afstemningen i 1920, og de valgte altså begge at tage konsekvensen af nederlaget. Elisabeth Mungard har meget kraftigt antydet, at valgnederlaget og gårdbranden ikke var de eneste grunde til, at han valgte at flytte væk. Hun skriver meget direkte, at forholdene i det Mungardske hjem var blevet for brogede til, at Nann kunne blive boende hos Jens. ${ }^{38}$ Nann døde den 30. juli 1935 og blev begravet på kirkegården i Møgeltønder, hvor hans gravsten fortsat står. Der er ikke noget, der tyder på, at Nann besøgte Sild efter, han flyttede fra øen, og Elisabeth har således beskrevet, hvordan han afslog at komme til hendes konfirmation.

Ved branden tabte Jens Mungard mange penge. Udbetalingen af pengene fra forsikringen udgjorde 56.000 mark, men han anslog, at det ville koste mellem trekvart og en million mark at genopbygge gården. Han udtrykte det med, at »forsikringspræmien var gennem alle årene blevet betalt i værdifaste penge og nu, efter ulykken, blev der betalt i næsten værdiløse papirmark «.39 Baggrunden for denne bitre kommentar er naturligvis, at inflationen i Tyskland i årene efter 
afslutningen af 1 . Verdenskrig var helt ude af kontrol, hvorved værdien af mark efterhånden helt faldt bort. Det var også grunden til, at det var noget nær en katastrofe for Jens Mungard, da hans værdifaste ejendom gik op i røg og blev erstattet af værdiløse marksedler. Alligevel betød branden ikke, at Jens sad tilbage i dyb fattigdom, og datteren har anført, at det ikke alene var økonomiske grunde, der forhindrede ham i at genopføre gården; han ønskede også at ændre sit liv.

Jens Mungard købte i stedet en mindre ejendom i Keitum med syv hektar jord, hvor han bortforpagtede hovedparten af jorden. ${ }^{40}$ Det gav hurtigt problemer, og i 1924 kunne forpagteren ikke længere betale. I mellemtiden havde Jens udvidet og bygget en ny lade, og han gjorde klar til selv at stå for bedriften fremover. Problemet var, at forbedringerne og investeringerne var foretaget $\mathrm{i}$ »dyre guldmark «, ligesom arbejdslønnen blev betalt dyrt. Der var således dyre lån i ejendommen, der skulle forrentes og afdrages.

I januar 1924 købte han en beboelsesejendom i Tönning med 120 beboelsesrum, og når man læser hans beretning om problemerne med denne ejendom, får man et klart indtryk af en mand, der følte sig ualmindeligt dårligt behandlet af de lokale myndigheder. Han fremstiller købet af ejendommen som en investering, der var god, da den blev foretaget, men som udviklede sig til at blive en økonomisk ruin, fordi myndighederne fjernede det økonomiske grundlag. Ejendommen var fra 1904/05, og den var ifølge Jens Mungard i god stand ved overtagelsen. Desuden fik han den til en god og betydeligt lavere pris, end den havde haft før krigen. Problemet var dog, at han kom til at betale en meget høj rente som følge af kurstab, hvorfor investeringen allerede fra starten hang $i$ en tynd tråd. For at gøre galt værre tvang myndighederne i Tönning ham til at udleje ejendommen til socialt belastede lejere til en fast, lav husleje, der var beregnet ud fra en særlig »Reichsmietengesetz«. Denne lov var midlertidig, hvorfor Jens Mungard ikke selv mente, at han havde handlet uansvarligt, da han købte udlejningsejendommen. Men da myndighederne efter købet forlængede loven, forsvandt det økonomiske grundlag bag investeringen. Ydermere gav myndighederne i Tönning, med borgmesteren Heinrich Altmann i spidsen, lejerne medhold i nogle krav om forbedringer af ejendommen, hvorfor Jens Mungards økonomi til sidst hang i laser.

Derfor valgte han i 1925 at bytte udlejningsejendommen i Tönning med et landarbejderhus i Archsum på Sild, men den juridiske sikring 
i forbindelse med dette mageskifte blev tilsyneladende ikke gennemført. I hvert fald anfører han selv, at det ikke blev tinglyst, og at denne mangel kom til at gøre livet endnu mere vanskeligt for ham. Det betød, at Jens Mungard overtog forpligtelserne på ejendommen i Archsum. Den nye ejer af ejendommen i Tönning sørgede for at kradse lejeindtægterne ind, men undlod at betale ejendomsskat. Derfor kunne Jens Mungard notere: »Til sidst var bykassen energisk, og da jeg stadig var registreret som indehaver af ejendommen, måtte jeg betale 2.550 RM i skat. « Da huset i Archsum derefter brændte samtidig med, at Jens Mungard havde averteret det til salg i avisen, blev han også anklaget for brandstiftelse. Sagen blev dog hurtigt frafaldet grundet manglende bevis, men der var fortsat usikkerhed om, hvem der ejede huset på grund af den manglende tinglysning. Det står hen i det uvisse, om han modtog forsikringssummen, men der blev under alle omstændigheder kun udbetalt 3.000 mark, hvilket dårligt kunne dække hans ekstra skattebetaling i Tönning. Efter branden fik han udlejningsejendommen tilbage, men da det ikke »havde økonomisk eksistensberettigelse, ansøgte jeg om en nedrivningstilladelse.« På den måde ville han kunne hente nogle penge på materialerne fra huset, men myndighederne nægtede at acceptere nedrivningen. Derfor kom ejendommen på tvangsauktion, hvor det ifølge Jens Mungard blev solgt til en brøkdel af værdien, »og alt, hvad jeg tabte, vandt Landesbank«. På trods af dette var han ikke forgældet, idet ejendommen i Keitum havde en skatteværdi på 56.000 mark, mens han kun skyldte 25.000 mark. Alligevel kom han i økonomiske problemer, fordi gården var nedslidt og jorden udpint. Vigtigere var det dog ifølge ham selv, at han efter tvangsauktionen var kendt som en dårlig betaler.

Det sidste, der er bevaret af udkastet til Jens Mungards erindringer, er en oplysning om, at hans svigermor i januar 1929 betalte 4.000 mark i arveforskud til sin datter. Penge som blev indskudt $\mathrm{i}$ bedriften. Det er uheldigt, at erindringerne slutter her, da vi derfor ikke ved ret meget om, hvad der skete i perioden frem til februar 1934, hvor Jens og Anna Maria blev skilt. Elisabeth Mungard har dog igen leveret nogle oplysninger. ${ }^{41}$ Først kunne hun fortælle, at Jens Mungard i årene efter, at dæmningen og jernbanen til Sild blev indviet i 1927, tjente gode penge på at udvinde grus og på at fragte det med hestevogn til banegården i Keitum. Det hang sammen med, at der under byggeboomet i slutningen af 1920'erne var stor efterspørgsel efter grus, og han tjente så meget på disse leverancer, at han havde råd til at købe en 
lastbil. Dette vidner i hvert fald om, at han på dette tidspunkt ikke led nogen økonomisk nød, men kort efter var han igen i alvorlig bekneb for penge. Gården i Keitum var på vej til at gå på tvangsauktion, fordi han ikke kunne betale renter og afdrag. I første omgang klarede han frisag ved at sælge noget jord fra, men kort efter blev der alligevel fastsat en dato for en tvangsauktion. Elisabeth Mungard mente, at han formentlig havde forventet, at hans hustru Anna Maria ville lade ham i stikken og forlade ham. Det gjorde hun også, men på en anden måde end Jens havde forventet. "Anna havde i mellemtiden lært noget og lugtede sin chance. I hvert fald skaffede hun sig en advokat, bød en sum penge, som hun ikke havde, og købte den [gården, MRN] inden tidspunktet for tvangsauktionen, solgte jorden til spotpris, hvorved huset var frit, og Jens var ude. Jens [...] kom ikke på den ide, at han ville blive bedraget.« Tror man på denne udlægning, blev Jens Mungard altså snydt af sin hustru, da hun overtog gården i Keitum i 1932. En anden mulighed kan være, at de i fællesskab aftalte forløbet for at forhindre, at ejendommen kom på tvangsauktion. På den måde kunne familien blive boende, og den yngste datter kunne fortsætte i skolen i Keitum. I hvert fald stod det klart, at Anna Mungards yngste datter, Nani Söderberg, overtog det møblerede hus i Keitum efter sin mor, hvilket Elisabeth øjensynligt ikke var tilfreds med.

Efter at Anna Maria Mungard havde overtaget huset i Keitum og efter skilsmissen to år senere, flyttede Jens Mungard fra Sild. I begyndelsen arbejdede han som forvalter på en gård i Angeln, og Elisabeth Mungard fortæller, at han var tæt på at gifte sig med enken på gården, men at han ikke turde på grund af de dårlige erfaringer fra sit tidligere ægteskab. Derfra flyttede han til Flensborg, hvor han fik arbejde som maskinist på en krydderimølle og flyttede ind i en lille lejlighed i Rødegade 36. I sit brev til Hermann Schmidt 31. juli 1938 ironiserede han over, at han i bogstaveligste forstand var "pebersvend «, idet han ene mand arbejdede sammen med 12 piger, der alle »var i den farlige alder «. ${ }^{42}$

Elisabeth Mungard undlod at fortælle hele historien om sin fars liv op gennem 1920'erne og i første halvdel af det følgende årti. I Schleswig-Holsteinisches Landesarchiv i Slesvig er der akter fra flere retssager, der blev ført mod Jens Mungard. ${ }^{43}$ Ifølge en optegnelse dateret 8. maj 1936 af »Der Strafregisterführer« var Mungard blevet idømt bøde- og fængselsdomme fem gange. Første dom for »tyveri« faldt 14. september 1923, hvorefter han skulle en måned i fængsel. Han 
blev idømt én dags fængsel 13. oktober 1927. I 1933 gik det hårdt for sig. Jens Mungard blev 12. august fængslet i en måned for tyveri. Allerede 29. september blev han igen dømt til en måneds fængsel for tyveri, men ved en ny dom 24 . oktober blev den samlede straf for de to tyveridomme nedsat til seks uger. Derefter gik det helt galt for ham, idet han 10. januar 1935 blev dømt for alvorligt tyveri og sat i fængsel frem til 10. marts 1936 - altså i mere end et år.

Der er altså meget, der tyder på, at Jens Mungard oplevede en voldsom social deroute i tiden kort efter den nazistiske magtovertagelse. Selv om regimet ikke var kendt for retssikkerhed, så må det betegnes som overvejende sandsynligt, at Jens Mungard begik kriminalitet i første halvdel af 1930'erne, og at dommene for berigelseskriminalitet ikke er vilkårlige. Omvendt forekommer det usandsynligt, at det har drejet sig om større summer, ligesom det er meget tænkeligt, at det var hans naboer, der fandt det belejligt at få et horn i siden på outsideren Jens Mungard. For regimet har det utvivlsomt været en god mulighed for at få styr på den kontroversielle mand.

\section{Problemer med det nazistiske styre}

Jens Mungard kom hurtigt på kant med det nye nazistiske styre efter magtovertagelsen i 1933. Det er uklart, hvorfor han fra begyndelsen blev opfattet som en fjende af regimet, men der er et par sandsynlige forklaringer. Der er ingen tvivl om, at naboerne på Sild huskede, at Nann Mungard ved afstemningen i 1920 havde agiteret til fordel for Danmark, og de kunne stadig huske, at »landsforræderen og spionens « gård var brændt ned året efter. Mungard-familien var på den baggrund outsidere på øen, og det forekommer naturligt, at både befolkningen og de nazistiske myndigheder har holdt øje med, hvad familien foretog sig. At Jens samtidig havde været i clinch med de lokale myndigheder i Tönning, og at han havde været under mistanke for brandanstiftelse i Archsum, giver grund til at formode, at de lokale nazistiske myndigheder opfattede ham som en mulig fjende af styret. Endelig var det nazistiske regime kendt for at gøre livet svært for kunstnere, der ikke fuldt og helt støttede op bag de nazistiske paroler. Derfor har det uden tvivl fra begyndelsen virket suspekt, at den tyske statsborger, Jens Mungard, valgte at skrive sine digte på et uforståeligt frisisk sprog. Men andre frisiske forfattere og kunstnere levede i nogenlunde fred for myndighederne, hvilket viser, at brugen 
af frisisk sprog ikke i sig selv kan være grunden til regimets forfølgelse af ham.

Thomas Steensen har anført, at Jens Mungard kort efter den nazistiske magtovertagelse var relativt positivt stemt over for det nye styre, fordi han havde forhåbninger om, at det ville være en fordel for friserne. ${ }^{44}$ Meget tyder på, at det er korrekt. I hvert fald skrev han i 1932 nogle digte, der må opfattes som positive over for nazismen. Wilts har ganske vist gengivet et digt med titlen »Nytårsparodi 1932«, hvor det blandt andet hedder: »I landsbyen er der mange, der skriger og skælder ud, hvordan skal de skaffe den slags summer. Derfor så de sig om efter hjælp, ja man længtes efter hans ankomst. En Hitler hjælper over sø og land, med sin heilende politiske armé.«5 Overskriften antyder, at digtet var ironisk ment, og han havde åbenbart ikke haft overdrevne forventninger om, at alt ville blive bedre, efter at Hitler overtog magten i landet.

Jens Mungard blev arresteret igen i 1936. Denne gang skyldtes det en simpel arvesag. Da Nann Mungard døde 30. juli 1935, efterlod han en bankbog i Tønder Landmandsbank til Jens med et indestående på 1.950 kroner. ${ }^{46}$ Det lyder ikke af meget, men omregnet til nutidskroner svarer det til ca. $65.000 .{ }^{47}$ Den første "Schutzhaftbefehl «, der er en nazistisk term, som nærmest kan oversættes til arrestordre, og som bestemt ikke har noget med beskyttelse at gøre, er dateret 13. juni 1936. Af den fremgår det, at Jens Mungard var arresteret og blev holdt fanget, fordi: »Deres hidtidige forhold retfærdiggør den begrundede mistanke, at De også fremover vil påføre Det tyske Riges anseelse svære skader i udlandet. De udgør dermed en umiddelbar fare for den offentlige sikkerhed og orden.« Det må opfattes som et helt absurd grundlag at arrestere ham på, og det bestyrker mistanken om, at der må være andre grunde til anholdelsen.

Af domsudskriftet fra 21. august 1936 bliver man ikke meget klogere. Det fremgår, at Jens Mungard havde undladt at gøre de tyske myndigheder opmærksom på, at han efter sin fars død havde et udenlandsk tilgodehavende, og at han ikke som foreskrevet havde tilbudt at overdrage pengene til den tyske rigsbank. Han blev kendt skyldig i anklagen, og det er noteret, at han skulle spærres inde, fordi hans relationer til Danmark gjorde ham til »fluchtverdächtig«. Han var altså mistænkt for at ville flygte.

Elisabeth Mungard var af den opfattelse, at hendes far blev angivet af en partitro nazist, der boede på Sild. Hun tænkte tilsyneladende 


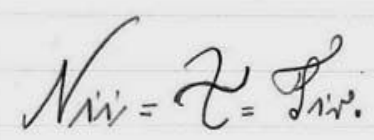

\section{$3 / 64$}

thi haw in Ack! \$i Mnos- Wimj wait!

Nonnters - Nacht es min fortic bi fen'.

Murs nuset mi me forier ew me fait

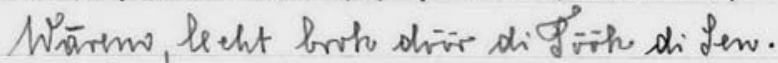

thi Maw iw Seh! Si Mto f forgair?

siar is Mleting hair ipp Lew en Mus.

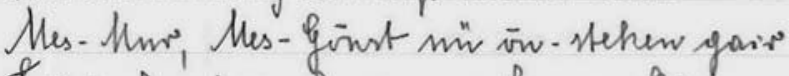

Sris en frombs en frai nuv Lew en basos.

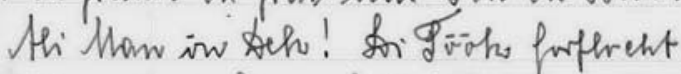

Mhro iow mis sa lung bifangew hairs.

Leell mi skints en halt siw hovgr Fercht.

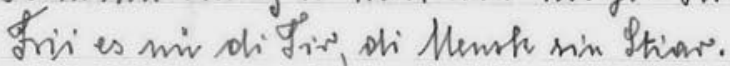

thi how wiw bek! In fris mi sinng

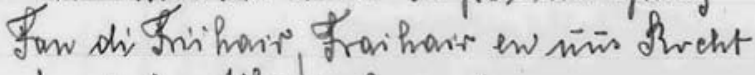

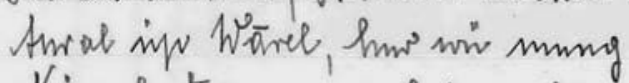

Nis wel stis enci, avarbri, weht en sheht.

Hem h. Anngaroh.

Digtet »Nii Tir - der betyder "Nye tider « - blev angiveligt skrevet $i$ 1932. Det må opfattes som positivt over for nazismen. Første vers: »Alle mand på dæk! Forårsvinden blæser! Vinternatten er nu forbi. Foråret kommer med lyn og torden. Sandelig bryder sollyset gennem tågen. "Foto: Arkivet ved Dansk Centralbibliotek for Sydslesvig (Hans Hoegs privatarkiv).

på en bestemt mand, der var tilflytter og levede som pensionist på Sild, hvor han som angiver til Gestapo var helt afhængig af de informationer, han kunne skaffe hos de lokale nazister på øen. På grundlag af hans oplysninger skred myndighederne til handling og 
arresterede Jens Mungard. ${ }^{48}$ Det er ikke klart, hvem hun hentyder til, men en mulighed kunne være udgiver af tidsskriftet Fuar Sölring Lir, Hermann Schmidt, der var nazist, og som op gennem 1930'erne havde udgivet mange af Jens Mungards digte. En anden mulighed kan være Carl Meyer, der også var nazist og forlægger i Westerland på Før. Det virker dog meget usandsynligt, at det er en af de to, hun hentydede til. I sit brev til Hans Hoeg har Elisabeth Mungard anført, at de penge, Nann havde stående på bankbogen ved sin død, formentlig var Jens' egne penge, idet Nann ikke havde mulighed for at spare penge op. Da Jens nogle år forinden havde besøgt Nann i Møgeltønder, havde han angiveligt lommerne fulde af penge, og det skulle have været en yderligere anstødssten til konflikt mellem Jens og Anna Maria. Derfor var det altså ifølge Elisabeth ingen arv, men hans egne penge Jens fik tilbage efter farens død i 1935. Ironisk nok ville det, hvis det er sandt, ikke have ændret de nazistiske anklager mod ham, idet han så netop kunne beskyldes for at have gemt penge af vejen i Danmark. Også selv om pengene var sendt til Danmark, inden nazisterne kom til magten. Det kan dog også tænkes, at nogle af dem, som Jens havde kostet penge, ønskede at straffe ham, da han igen kom til penge.

Jens Mungard opfattede ikke sig selv som nogen politisk digter. Han skrev 31. juli 1938 et brev til sin udgiver, Hermann Schmidt, kort efter, at han af »Reichschriftungskammer « havde fået skriveforbud: »Jeg skriver ikke politisk, og derfor kommer jeg heller ikke i berøring med de dagsaktuelle politiske spørgsmål. Det er mig ubekendt, om du og Meyer ${ }^{49}$ som partimedlemmer repræsenterer det samme standpunkt. Dem, der ikke skriver Hitler-hymner, må ikke længere skrive, og sådanne skriver jeg ikke, men jeg skriver heller ikke det modsatte. $\mathrm{Nu}$ mangler det blot, at min finger bliver hakket af. « ${ }^{50} \mathrm{I}$ den korte, men meget interessante artikel af Ommo Wilts fra 2010 med den sigende titel »Frisisk lyrik som modstand « har han netop fremhævet, at Jens Mungard skrev nogle stærkt kritiske digte vendt mod det nazistiske styre. Og at han efter krigen netop blev opfattet som en digter, der havde ydet modstand mod regimet.

Efter sit første fængselsophold i 1936 skrev han digtet »Tremmer for vinduet «, hvor han på poetisk vis gav udtryk for sine oplevelser: ${ }^{51}$ 


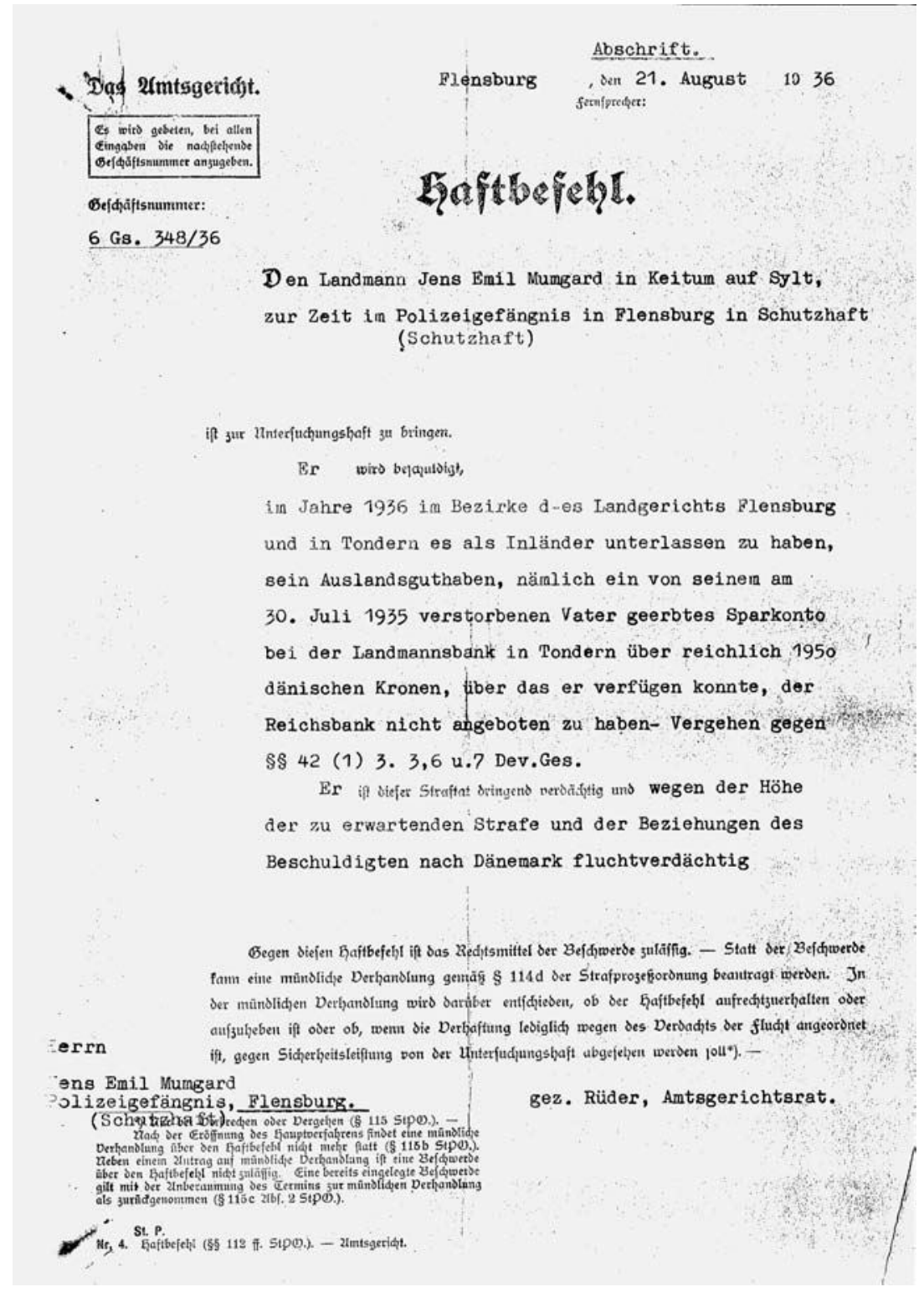

Fotokopi af en »Haftbefehl « dateret 21. august 1936. Jens Mungard blev arresteret $i$ 1936, fordi han ikke havde opgivet en arv efter sin far på 1.950 kr. i Tønder Landmandsbank. Begrundelsen for fxngslingen var, at myndighederne var bange for, at han ellers ville flygte til Danmark. Foto: Arkivet ved Dansk Centralbibliotek for Sydslesvig (Hans Hoegs privatarkiv). 
Ind gennem vinduet, mellem tremmerne, skinner månen bleg og mild.

Som kunne den troste mig, til intet at forstå af denne situation.

I haven, i træerne synger fuglene morgen og aften.

Hvis de sang politiske sange, ville preusserne ${ }^{52}$ skride ind.

I buskene vil nogle drenge, gribe og fange en drossel. Fløjte skal den ikke længere, men den undslipper dem dog.

Har ingen mennesker revet et ben af, eller også kun sagt sandheden.

Jeg har dog kun skrevet nogle sange, som jeg opfører på dette sted.

Det må opfattes som et digt skrevet af en mand, der følte sig umådelig dårligt behandlet af et undertrykkende styre, men som vel heller ikke rigtig forstod, hvad han havde gjort galt. Han skrev også et andet digt, som mindede meget om dette, men som var endnu tydeligere $\mathrm{i}$ sit indhold, ${ }^{53}$

Jerndøre, gittervinduer, og om huset går en vagtpost.

Gemt vak som en ener,

så man ikke kan forvolde staten skade.

Vær ikke vred, du skal ikke skælde ud, hold blot mund og kxft.

Fra et "Schutzhaftperspektive",

Ser sagen anderledes $u d$. 
Det var først fra 1934, at han for alvor begyndte at skrive kritiske digte om det nye styre. Og fra dette tidspunkt blev han i stigende grad en politisk digter, der udtrykte sin afstand fra nazismen.

Han startede med ironiske digte som »En måneskinsnat er aldrig så smuk, som når man tramper i kolonner«, gående over til mere direkte politiske digte som "Går du ikke med ind i vores venskab, efterkommer du ikke vore ønsker, da slår vi hjerneskallen ind på dig! Er den slags rigtigt mellem mennesker? «4

Han skrev flere stærkt kritiske digte om antisemitisme og kort efter, at en ældre jødisk mand i Keitum var blevet anholdt og bragt til Slesvig, skrev han;

Landsmænd! 55

Jeg tør næsten ikke sige det til jer, men kan dog heller ikke fortie det. Hvordan de her er kommet langt, med at drive jødehetz.

De fandt da også en gammel mand, han var i 80'erne.

Den forrige stat havde frataget ham, hans penge, hans gods og hans varer.

Der var ingen, der hilste på ham på hans vej, og ingen havde noget med ham at gøre.

Med jøder uden penge er der her $i$ landet ingen, der vil have noget med at gøre.

Der hersker ingen tvivl om, at Gestapo havde hæftet betegnelsen »upålideligt politisk element « på Jens Mungard, og de har holdt nøje øje med ham i hvert fald efter, at han slap ud efter den første fængsling. Forbuddet mod at skrive må tages som et udtryk for, at han i stigende grad blev en belastning for regimet. Samtidig kunne et digt som det ovenstående »Landsmænd « i den grad have skabt fjender i Keitum og på Sild, hvis ellers digtet var blevet offentliggjort. Men det blev det og de øvrige politiske digte ikke. Hans faste udgiver, Hermann Schmidt, kunne under det nazistiske styre kun med stor forsigtighed risikere at udgive hans digte, hvilket ikke omfattede de politiske. ${ }^{56}$ Det er derfor også meget tvivlsomt, om Gestapo havde kendskab til digtene, og om 
det ligger til grund for, at han ad to omgange blev fængslet. Skal man tro de breve, han sendte til Hermann Schmidt, så udtrykte han nok sin utilfredshed med og sin uforståenhed over for, at han var blevet arresteret og blev holdt indespærret. Som anført var han også meget kritisk over for, at han i 1938 blev nægtet at skrive. Men der er ikke noget, der tyder på, at han har sendt sine politiske digte til Schmidt, Meyer eller andre. Digtene er først blevet offentliggjort af Hans Hoeg længe efter krigens afslutning, så det er formentlig ikke dem, der var grunden til, at han blev sendt til Sachsenhausen.

Jens Mungard blev hentet af Gestapo 23. december 1938, og denne gang kom han ikke ud igen. ${ }^{57}$ Halvandet år forinden, 1 . august 1937, havde han gjort sin datter, Elisabeth, til enearving. I sit brev til hende understregede han, at hun ikke var forpligtet til at tænke på sine søskende. Han opremsede kort, hvad han ejede, og forklarede desuden, at »der befinder sig et gennemslag af alt, jeg har skrevet på frisisk i Sønderjysk Bibliotek i Toftlund, og et andet gennemslag sendes snart til Universitetsbiblioteket i Aarhus«. Det antyder både en nær forbindelse til relevante institutioner i Danmark og et håb om, at arbejdet ville blive opbevaret i sikkerhed i Danmark.

Frem til 5. marts 1939 var han indespærret i Flensborg, hvorefter han blev overført til koncentrationslejren Sachsenhausen ved Berlin. I lejren blev der især i de første år indsat forholdsvis mange politiske fanger, og Jens Mungard må betragtes som en sådan. Han blev i hvert fald opfattet som en modstander af styret, og det har formentlig været grunden til, at han blev sendt i koncentrationslejr. Der er bevaret meget lidt fra hans kz-ophold, og datteren beklagede i sit brev til Hans Hoeg, at det kun var få af hendes fars breve, der var kommet gennem censuren. Men når han kun overlevede i omkring 11 måneder i lejren tyder alt på, at han var afkræftet, da han ankom dertil, og at de dårlige forhold i lejren hurtigt pinte livet ud af ham. Det indledende citat af medfangen Lienau antyder mildt sagt ingen barmhjertighed, da han blev syg med lungebetændelse, og for det nazistiske regime var det da også kun en fordel, at han døde.

Ifølge Ommo Wilts skrev han nedenstående digt "Ik Büch mi ek «»Jeg bøjer mig ikke« - mens han sad i Sachsenhausen. ${ }^{58}$ Det giver i hvert fald god mening, hvis han gjorde. Det er skrevet af en mand, der allerede har fået mange klø, og som ikke havde nogen fremtid: 


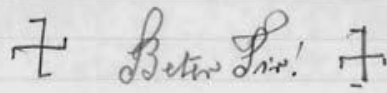

$3 M \quad 37$

Ln Trits hair hew anw ali saragew

P Inw just jie mint is for'y en Hillargew in träch oping mi diver Nacht en Fivk in hir minu trai muar fing of Itag.

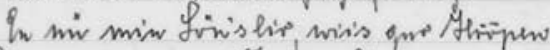

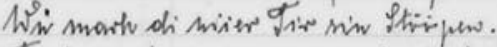

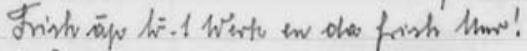

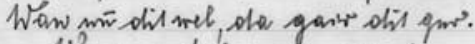

1Paw mi lis hro da ali strumi

ta hjer of tourel sins ch hrouns.

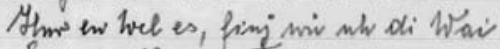

in elere Nacht en Iroh nur f thar.

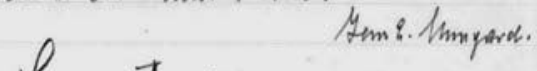

Lecht-Maac siv! Niv weagi gri sir Macht

$$
\text { Lew If haal }
$$

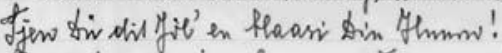

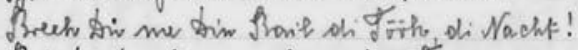

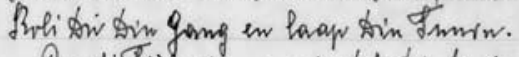

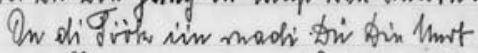

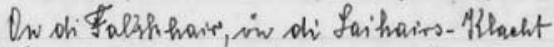

Frish app! en oha: At: Man in Bunar

Srish app tis olil Leesenor, tis di Jacht.

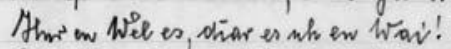

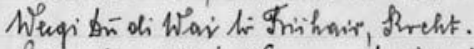

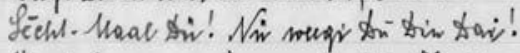

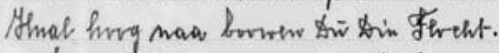

te wat flan es nut fmar tis for gnng.

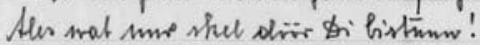

tirarrno wel wis hivipi, wet nis sjung

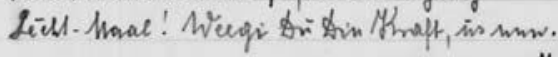

$$
\text { Mons. Mnny arok. }
$$

Kopi af to håndskrevne, dekorerede og signerede digte med titlerne »Beter tir « - »Bedre tider « - og »Licht Maal « - Lyssignal «. Digtene er angiveligt skrevet i 1932. Jens Mungard kom meget hurtigt på kant med det nazistiske styre. Op gennem 1930'erne skrev han adskillige stærkt kritiske digte, som dog først er blevet udgivet inden for de seneste to-tre årtier. Men 1932 skrev han endnu positivt om nazismen som i digtet »Beter tir «»Bedre tider«. Foto: Arkivet ved Dansk Centralbibliotek for Sydslesvig. 
Og siger de, at jeg er en sprgefugl,

da tager jeg det ikke fortrædeligt op.

Jeg pifter efter de mange,

men det rager mig ikke en døjt.

Og vil de da true mig,

til at jeg skal trække kærren op af dyndet for dem.

Skal den slags glæede mig:

Gør det dog selv.

Og hois de vil hente mig,

og tvinge mig dertil.

Jeg vil aldrig slave for dem,

det må de gøre selv.

Elisabeth Mungard modtog en ultrakort besked 15. februar 1940 med teksten »Vater an Körperschwäche verstorben. Kommandant«. Fem dage senere modtog hun et mere udførligt brev. I dette brev, der var underskrevet af lejrkommandanten Dannel, blev det forklaret, at Jens Mungard 13. februar kl. 08.00 havde lidt en pludselig hjertedød som følge af hans stærkt svækkede sundhedstilstand. Døden havde været meget rolig, og han havde ikke efterladt noget skriftligt eller mundtligt til sine efterladte. Det blev oplyst, at han var blevet kremeret, og ved at betale et »overføringsgebyr« på tre Reichsmark og sende en attest fra en kirkegårdsforvaltning, ville det være muligt at få urnen tilsendt. Ellers ville urnen blive begravet »Kostenlos«. Den afdødes ejendele ville »i løbet af de næste dage « blive sendt til Elisabeth Mungards adresse. ${ }^{59}$ Brevet er altså skrevet i et meget høfligt sprog, og det kunne lige så godt have drejet sig om handel med varer. Når man tager omstændighederne i betragtning, hvor de nazistiske myndigheder havde pint livet ud af en politisk modstander, må det have været et grotesk brev at modtage for Elisabeth Mungard: at få tilbudt sin fars urne mod at betale et gebyr til at dække statens omkostninger. Martin Sadek har i udstillingskataloget anført, at den eneste grund til, at Elisabeth modtog dette høflige uddybende brev, var, at hun tidligere havde været leder i den nazistiske pigeorganisation, Bund Deutscher Mädel, og at hun derfor af regimet blev regnet som en god nazist. ${ }^{60}$ Denne oplysning er ikke bekræftet andre steder, men det forekommer ikke sandsynligt, at Elisabeth har været glødende nazist i slutningen af 1930'erne, hvor hendes far i stigende grad blev forfulgt. 
I 1956 sendte Jens Mungards datter, Helene, en ansøgning til »Landesentschädungsamt Schleswig-Holstein «, der var en vesttysk myndighed, som kunne tilkende erstatning til mennesker, der var blevet forfulgt under det nazistiske styre af politiske eller racemæssige grunde. Datteren søgte om erstatning for hendes fars død i Sachsenhausen. ${ }^{61}$ I et svar dateret 5. januar 1957 blev ansøgningen afslået, fordi myndighederne ikke fandt det godtgjort, at det var politiske forhold, der medførte, at Jens Mungard havde været indsat i kz-lejren. I afslaget henviste man til, at Mungard i januar 1935 var blevet idømt et års fængselsstraf for »alvorligt tyveri«, og at han i 1936 var blevet fængslet for overtrædelse af pas- og valutalovene. »På grund af disse omfattende domme og de manglende konkrete holdepunkter om, at den afdøde var modstander af nationalsocialismen, er det med en sandsynlighed grænsende til sikkerhed, at det var kriminelle årsager, der lå til grund for anbringelsen i Koncentrationslejr Sachsenhausen.«

Myndighederne mente derfor ikke, at man kunne tildele erstatning, fordi Mungard ikke havde været politisk forfulgt. Kendelsen forekommer problematisk. Selv om man vælger at tro på, at fængslingerne af Jens Mungard i årene 1935-1937 skyldtes kriminalitet, og at dommene faldt efter en fair retssag, så havde han udstået sin straf $\mathrm{i}$ 1937. Da han blev arresteret i december 1938 og efterfølgende indsat i Sachsenhausen, skete det uden dom, og der er ingen antydning af, at det skyldtes kriminelle handlinger. Derimod fremgår det af samtidige dokumenter, at Gestapo i 1937 og 1938 overvågede Jens Mungards gøren og laden, og det forekommer overvejende sandsynligt, at det var Gestapo, der arresterede Mungard og sendte ham til Sachsenhausen.

\section{Må ikke oversættes til tysk}

I 1938 skrev Jens Mungard på titelbladet til en sammenstilling af sine skrifter: »Aurséten ön Dütsk Spraak es forböören «, hvilket betyder »Oversættelse til det tyske sprog er forbudt «. ${ }^{62}$ Dette forbud gav i slutningen af 1980 'erne anledning til en del postyr. Karl Schmidt var blevet så fascineret af Jens Mungards digte, at han havde oversat dem til tysk. Sammen med Nordfriisk Instituut var det aftalt, at de oversatte digte skulle udgives, og de var stort set gået i trykken, da Hans Hoeg nægtede at tillade udgivelsen. Når Jens Mungard havde nægtet, at digtene nogensinde blev oversat til tysk, ville Hoeg ikke acceptere 


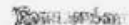

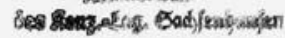

z: 14 b $1 / 2475 /-\operatorname{sch} 1$.

Oranienburg, den $20.2 \cdot 1940$

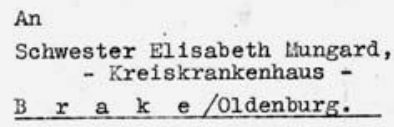

Die Kommandantur des Konzentrationslagers Sachsenhausen hat Ihr Schreiben vom 15.Febr.d.Js. zur Kenntnis genommen und teilt ait, daB Ihr Vater am 13. Februar 1940 um 8,00 Uhr an allgemeiner Körperschwäche mit plötzlichem Herztod im Krankenbau des K.I.Sh. verstorben ist.

Nach fussage des Lagerarztes hatte er einen sehr ruhigen sod und hat nach niemenden verlangt und auch nichts Schriftliches oder witindiches hinterlassen.

Der Tod wurde bei dem Standesamt in Oranienburg registriert; hierbei sei erweähnt, daß, falls Sie Sterbeurkunden benötigen, diese dort schriftlich anzufordern sind.

Die Leiche wurde alsdann dem Krematorium in Fürstenberg/Zecklgb zugefihrt, woselbst sie auf Staatskosten eingeäschert wird. Falls Sie an der tberfuhrung der Urne Interesse haben, so ist diese unter Beifligung einer Uberfihrungsgebihr von Ru 3,-und einer Bescheinigung der für Ihren \#ohnsitz zustänåigen Friedhofsverwal tung diruber, dab eine Stelle fur die Urnenbeisetzung vorhanden ist, schriftlich bei dem vorgenannten Krematorium enzufordern. Geschieht dies nicht, so findet eine Zeisetzung in dem Urnenheim kostenlos statt.

Alle affekten und Zertgegenstände, sofern sie Ihr Vater hier hatte, werden in den nächsten Iagen an Ihre Adresse zur Absendung gelangen.

Die Kommandantur hofft, Ihnen mit Vorstehendem gedient zu haben.

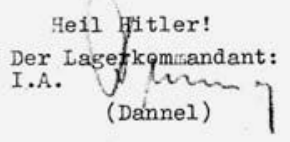

113. Irgendwelche Kosten sind Ihnen durch den rod bezw. derch die Bestattung nicht entstanden.

$$
\text { D.O. }
$$

Kopi af brev fra lejrkommandanten i koncentrationslejr Sachsenhausen, Dannel, til Elisabeth Mungard, dateret 20. februar 1940. Elisabeth Mungard modtog dette brev efter sin fars død i februar 1940. Brevet var skrevet $i$ et høfligt forretningssprog, der dog ikke skjulte det triste budskab. Foto: Arkivet ved Dansk Centralbibliotek for Sydslesvig. 
udgivelsen. I løbet af april måned 1987 blev der skrevet nogle breve mellem Hoeg og Schmidt, der var venlige på overfladen, men som ikke skjulte uenigheden mellem dem. Resultatet blev, at digtene ikke blev udgivet på tysk, og indtil videre er det kun Ommo Wilts og et par andre, der har fået lov til at oversætte og udgive enkelte digte på tysk. Dog har Nordfriisk Institut i 2013 udgivet omkring 100 digte på frisisk og tysk i Jens Mungard. Dechtings - Gedichte, der er redigeret af Ingo Laabs.

Det bringer naturligvis spørgsmålet frem, om oversættelsesforbuddet gjaldt alle Jens Mungards digte, fordi den nævnte håndskrevne kommentar er det eneste sted, hvor forbuddet er skrevet. Mungard har ikke skrevet det i sit testamente eller andre steder. Og hvis forbuddet var gældende, rejser det spørgsmålet, om det fortsat skal overholdes, og om det nogensinde skal kunne lade sig gøre at udgive de oversatte digte. Schmidt skrev i det ovenfor nævnte brev, at »jeg levede med den forhåbning, at vores højtyske gengivelse, der stammer fra et andet Tyskland, også ville have vundet anerkendelse hos digteren Jens Mungard $\ll .63$

Man må opfatte dette oversættelsesforbud som Jens Mungards opgør med alt tysk på et tidspunkt, hvor de nazistiske myndigheder i Tyskland undertrykte ham og andre, der gik imod regimet. Derfor er forbuddet fuldt forståeligt. Han har ikke ønsket at forhindre, at digtene blev oversat til dansk eller andre sprog, men det er aldrig blevet gjort. Det er en vigtig grund til, at Jens Mungard fortsat er en temmelig ukendt digter, fordi frisisk kun forstås af ganske få mennesker. $\mathrm{Og}$ den frisiske dialekt på Sild, Sölring, forstås af endnu færre. Desuden var det først med Hans Hoegs arbejde i 1980'erne, at digtene samlet blev udgivet, mens de indtil da lå gemt væk eller for længst var blevet glemt efter, at de inden krigen havde været trykt i aviser på Sild.

Alligevel regnes han i dag for at være en af de vigtigste frisiske digtere overhovedet. Allerede i 1949 skrev L.C. Peters at, »Jens Mungard er den dybsindigste, den mest fantasibegavede og den ordmægtigste sildringske [Sylter, MRN] digter. « ${ }^{64}$ Det skete efter, at han kort havde forklaret, at Mungard havde haft et svært liv, og at han havde været et kompliceret menneske, »der ofte kom i konflikt med sine omgivelser.« Man skal bide mærke i, at denne korte beskrivelse udkom i det nyetablerede Nordfriisk Instituuts årsskrift på et tidspunkt, hvor mange fortsat kunne huske Jens Mungard. ${ }^{65}$ Der har formentlig været grænser for, hvor langt Peters kunne gå, idet Jens Mungard 
fortsat på øen blev regnet som en noget besværlig særling. Han havde både irriteret mange i lokalsamfundet samtidig med, at han repræsenterede et oprør mod et system, som mange nordfrisere gerne ville glemme, at de selv havde støttet.

Som nævnt i indledningen blev Jens Mungard i 1960 i Deutsche Philologie im Aufriss betegnet som »Den betydeligste nordfrisiske digter i vore dage « ${ }^{66}$ Derefter blev han stort set ikke omtalt, inden Hans Hoeg gjorde noget ved det i begyndelsen af 1980'erne. Dog betegnedes han som »Den store mands store søn« i Sylt fra 1980, hvilket som nævnt fik datteren Elisabeth Mungard og Hans Hoeg på banen med et andet syn. De mente, at det var forfejlet udelukkende at se Jens Mungard i skyggen af sin far. Hoeg har beskrevet ham som »den altoverskyggende digter, der alene havde bestået grundskolen, blev en af vore få digtere, der ud fra en indre trang fandt sin tilfredsstillelse ved at virke for sit land og sit folk, for sit sprog og for bevarelsen af frisernes frihed $« .67$

Nogenlunde samtidig skrev Karl Schmidt en kort artikel om Jens Mungard. Schmidt boede i Rodenäs tæt på den dansk-tyske grænse og havde som nævnt ovenfor oversat mange af Mungards digte til tysk, uden at Hoeg ville tillade, at de blev udgivet. Han sluttede artiklen med at konstatere: »Vi må fremhæve ægtheden i Jens Mungards lyrik. Han var en digter. « ${ }^{68}$ Schmidt vurderede lyrikken uden at skele ret meget til mennesket Jens Mungard og den betydning, hans personlige historie havde for hans digte.

Da Slesvigland i 1985 udgav en kort artikel om Jens Mungard, valgte de at gengive Hermann Schmidt og professor Brouwers vurdering fra 1962 til at illustrere værdien af Mungards arbejde: »Den bedste sildringske skribent i vor tid var Jens Mungard. I hans hjerte levede en dyb kærlighed til vor $\varnothing$ og frihed af enhver art forsvarede han i handling, ord og skrift. Det var et meget sørgeligt endeligt for en stolt og rank Sild-friser. - Hans værk lever, og vi sildringer kan ikke være ham tilstrækkelig taknemlige for det. ${ }^{69}$

Ommo Wilts var akademisk direktør for Nordfriesischen Wörterbuchstelle ved universitetet i Kiel, indtil han blev pensioneret i 2002. Han har flere gange skrevet noget om Jens Mungard. Wilts vurderer ikke blot Mungards lyrik; han er også gået bag om mennesket, når han har vurderet digtene. ${ }^{70}$ I det indledende abstract til den sidste artikel noterede han: »Landmanden Jens Emil Mungard, der blev født i 1885 i Keitum og døde i KZ Sachsenhausen i begyndelsen af 1940, 
er vel ud fra indholdet af sine værker den mest betydningsfulde nordfrisiske lyriker. $\ll^{71}$

Endelig har dr. Thomas Steensen, der er direktør for Nordfriisk Instituut, skrevet om Jens Mungard flere gange. Han begyndte den korte biografi i Das Neue Sylt Lexikon med at notere: »Jens Mungard går for at være en fremragende digter på det nordfrisiske sprog. Denne erkendelse kom dog først frem længe efter hans død." Steensen kommer således med den væsentlige pointe, at det først er inden for de seneste årtier, at digteren Jens Mungard er kommet til ære og værdighed, fordi mennesket Jens Mungard i sin samtid var så kontroversiel, at det overskyggede det lyriske.

\section{Afrunding}

»Du vil beskrive Jens' tanker og følelser. Her har jeg nærmere den opfattelse, at du beskriver dine egne tanker og følelser. Du har kun forestillingen om Jens ud fra hans arbejde. Dette taler for sig selv og kræver ingen beskrivelse [...] Ingen mennesker kan se ind i sjælen på en anden, og den, der bliver set ind i, skal kunne forsvare sig. [...] Jens ville sige: Hvad vedkommer mit inderste andre! Han har aldrig skrevet for at være den store digter, der skal fejres. Han skrev af fornøjelse og glæde - og jeg mener, at man skal lade ham bevare det i døden. «72

Sådan skrev Elisabeth Mungard til Hans Hoeg i januar 1983, efter at Hoeg havde sendt hende et udkast til en biografi om Jens Mungard. Det var baggrunden for hendes mange kontroversielle oplysninger i sit brev. Alligevel kan man anføre, at hendes formaning i mindst lige så høj grad gælder min fremstilling af Jens Mungard, og det er naturligvis i meget høj grad mine vurderinger af manden, der kommer til udtryk i denne artikel. Men det er ikke blot en historikers opgave at beskrive, hvad der skete; opgaven er i højere høj grad at analysere, hvorfor det skete. Som også Ommo Wilts har gjort det i sine artikler, er det min opfattelse, at for at kunne forstå indholdet af Jens Mungards digte, må man forsøge at forstå baggrunden for dem. Det er afgørende at forholde sig til det komplicerede forhold mellem far og søn og mellem mand og hustru for at kunne vurdere baggrunden for indholdet af Jens Mungards lyriske arbejde.

Det er efterhånden så mange år siden, at denne historie udspillede sig, at de involverede for længst er døde, men der hersker næppe 
tvivl om, at de særlige forhold i Mungard-familiens hjem i Keitum var en offentlig hemmelighed i landsbyen. Det har formentlig været en medvirkende årsag til, at familien blev skudt længere og længere ud fra landsbyfællesskabet. Og en grund til, at de nazistiske myndigheder straks efter magtovertagelsen i 1933 begyndte at holde øje med Jens Mungards gøren og laden.

Jens Mungards liv var på mange måder en trist historie, men det dannede en vigtig baggrund for hans mange digte, der altså i dag vurderes højt. Men da digtene er skrevet på Sölring, det frisiske sprog på Sild, har de kun kunnet læses og forstås af meget få mennesker. Det har begrænset udbredelsen betragteligt, fordi forfatteren samtidig nægtede, at digtene måtte oversættes og udgives på tysk. Uanset at der er blevet løsnet op for dette forbud, er det ikke helt ligetil at oversætte digtene til tysk, dansk eller et andet sprog, idet der går noget tabt ved oversættelsen; hvis det poetiske vægtes højt i oversættelsen, kan det gå ud over indholdet, og hvis hovedvægten lægges på betydningen - som det er tilfældet i denne artikel - kan det gå ud over det poetiske. Desuden har digtene været gemt og glemt siden 1930'erne, indtil Hans Hoeg i 1980'erne og 1990'erne fik dem udgivet. Det har naturligvis virket stærkt hæmmende for kendskabet til hans digte.

Med digtet »Strandtidslen er min blomst « har Jens Mungard skrevet en slags nekrolog over sig selv. ${ }^{73}$ Derfor sluttes artiklen med dette korte digt:

Strandtidslen er min blomst, strandtidsel kaldes også jeg.

Den gror $i$ klitsand, som jeg på livets strand, og torne har vi begge to.

\section{KILDER}

Utrykte kilder:

DCB: Arkivet ved Dansk Centralbibliotek for Sydslesvig.

Arkiv nr. A1138, Jens Mungard.

Arkiv nr. A1139, Nann Mungard.

Arkiv nr. A1719, Hans Hoeg.

SHL: Schleswig-Holsteinisches Landesarchiv.

Abt. 761, Nr. 24107.

Abt. 357.1, Nr. 208. 


\section{LITTERATUR}

Brouwer, J. H. og H. Schmidt: Dit Leewent en broket Kraans. Söl'ring Steken üp Riimen fan Jääns Mungard, Drachten 1962.

Hoeg, Hans: Jens Mungard. Fuar di min hart heer slain, Bräist/Bredstedt 1985.

Hoeg, Hans (red.): Nann Peter Mungard 1849-1935. Der Friese Jan. Lebenserinnerungen eines Sylter Kapitäns, Amrum 1989.

Hoeg, Hans: Jens Emil Mungard 18851940. Ströntistel en Dünemruusen. Das Lyrische Werk, Amrum 1995.

Lienau, Heinrich: Zwölf Jahre Nacht. Mein Weg durch das "Tausendjährige Reich«, Flensburg 1949.

Mungard, Jens: Dechtings - Gedichte. Mit Nachdichtungen von Ingo Laabs und Karl Schmidt-Rodenäs, Bräist/ Bredstedt 2013.

Peters, L.C.: «Nordfriesische Dichter», Jahrbuch des Nordfriesischen Instituts, Bredstedt 1949, s. 151-162.

Schmidt, Hermann: «Zur Geschichte des Syltringischen Schrifttums II», Nordfriesches Jahrbuch (Neue Folge), Bredstedt 1976, s. 120-130.

\section{NOTER}

1. Lienau 1949, s. 66.

2. Han kaldes herefter Jens Mungard.

3. Steensen 2011, s. 23.

4. Her citeret efter Slesvigland, 1985, s. 107.

5. Wilts 1985 og 2010. Gennem hele artiklen har jeg oversat direkte fra frisisk med hjælp af Marie Tångeberg. Det er tilstræbt, at oversættelserne gengiver indholdet af digtene så nøjagtigt som muligt, hvilket eventuelt er gået ud over den poetiske fremtoning.

6. Arkivet ved Dansk Centralbibliotek for Sydslesvig (herefter DCB), arkiv nr. A1719.

7. DCB, arkiv nr. A1719, breve fra Elisabeth Mungard dateret hhv. 25.1.1983 og 19.1.1983.
Schmidt, Karl: «Die Lyrik Jens Mungards. Eine Formstudie», Nordfriesisches Jahrbuch. Band 25, Bredstedt 1989, s. 17-25.

Simon, Sven m. fl.: Sylt. Abenteuer einer Insel, Hamburg 1980.

Küssner, Dieter, (red.): »Jens Mungard - en frisisk digter ", Slesvigland, 1985, s. 101-109 og s. 126.

Steensen, Thomas: Die friesische Bewegung in Nordfriesland im 19. und 20. Jahrhundert (1879-1945), Neumünster 1986.

Steensen, Thomas: Das Neue Sylt Lexikon. Neumünster 2007.

Steensen, Thomas: «Er starb den Tod der Unterdrückten und Gequälten. Ehrung für Jens Mungard «, Nordfriesland, nr. 176, 2011, s. 21-23.

Wilts, Immo: «Jens E. Mungard. Zu seinem hundertsten Geburtstag am 9. Februar 1985«, Nordfriesland, nr.75, 1985, s. 39-43.

Wilts, Immo: «Friesische Lyrik als Widerstand. Werk und Schicksal von Jens Mungard (1885-1940)«, Nordfriesland, nr. 172, 2010, s. 21-26.

8. I denne artikel benyttes Hans Hoegs publikation Der Friese Jan fra 1989.

9. DCB, Jens Mungards arkiv nr. A1138 og Nann Mungards arkiv nr. A1139.

10. DCB, arkiv nr. A1719, brev fra Elisabeth Mungaard til dr. Thomas Steensen, dateret 19.1.1983 og DCB, arkiv nr. A1138, Jens Mungards ufuldstændige udkast til sine erindringer, der standsede brat i slutningen af 1920'erne.

11. Stavemåden på bedstefarens efternavn varierer mellem Munkgaard, Mongaard, Mungaard og Mungard. Hoeg har kaldt ham for Claus Nielsen Mongaard, mens både Jens og Elisabeth Mungard kalder ham Claas Niels Mungard. 
12. DCB, arkiv nr. A1719, brev fra Elisabeth Mungard til Hans Hoeg, dateret 25.1.1983.

13. DCB, arkiv nr. A1138.

14. Hoeg 1989, s. 7-9.

15. Hoeg 1989 , s. 1.

16. DCB, arkiv nr. A1719, brev fra Elisabeth Mungard til Hans Hoeg, dateret 25.1.1983.

17. Om Li Hung-chang læs f.eks. beskrivelsen på encyclopedia.com.

18. Hoeg 1989, s. 166-177.

19. DCB, arkiv nr. A1719, brev fra Elisabeth Mungard til Hans Hoeg, dateret 25.1.1983.

20. DCB, arkiv nr. A1138.

21. DCB, arkiv nr. A1138.

22. DCB, arkiv nr. A1138.

23. DCB, arkiv nr. A1138, Jens Mungards udkast til sine erindringer og arkiv nr. A1719, brev fra Elisabeth Mungard til Hans Hoeg, dateret 25. 1.1983 samt Hoeg 1989, forordet.

24. Hoeg 1989, forordet.

25. Dette afsnit er baseret på DCB, arkiv nr. A1719, brev fra Elisabeth Mungard til Hans Hoeg, dateret 25.1. 1983.

26. Ibid.

27. Simon m.fl. 1980 , s. 254.

28. DCB, arkiv nr. A1719, brev fra Elisabeth Mungard til Hans Hoeg, dateret 25.1.1983 og til Thomas Steensen, dateret 19.1.1983.

29. Dette afsnit er baseret på DCB, arkiv nr. A1138, Jens Mungards udkast til sine erindringer.

30. Nann Mungard har anført, at branden fandt sted natten mellem 12. og 13. januar, jf. Hoeg 1989, s. 324.

31. DCB, arkiv nr. A1138, Jens Mungards udkast til sine erindringer.

32. Ibid

33. Dette afsnit er baseret på Hoeg 1989, s. 290-342.

34. Cornelius Petersen kom fra Ejdersted, men havde inden afstemningen overtaget en gård ved Møgeltønder. I løbet af 1920'erne var han hovedmand bag den såkaldte selvstyrebevægelse i Sønderjylland. Cornelius Petersen var kort sagt en kon- troversiel skikkelse under afstemningskampen og $\mathrm{i}$ årene derefter.

35. Hoeg 1989, s. 292.

36. Lornsen var fra Sild, og han var embedsmand i den danske helstat. I 1830 blev han udnævnt til landstrandfoged på Sild, og han forfattede samme ăr skriftet Ueber das Verfassungswerk in Schleswig-Holstein, der fik stor betydning for den nationale kamp i årene op til udbruddet af Treårskrigen i 1848.

37. Hoeg 1989, s. 324.

38. DCB, arkiv nr. A1719, brev fra Elisabeth Mungard til Hans Hoeg, dateret 25.1.1983.

39. DCB, arkiv nr. A1138, Jens Mungards udkast til sine erindringer.

40. Dette og de følgende to afsnit er baseret på DCB, arkiv nr. A1138, Jens Mungards udkast til sine erindringer. Oplysningerne er ikke efterprøvet andre steder, så det er hans udlægning der gives.

41. Dette afsnit er baseret på DCB, arkiv nr. A1719, brev fra Elisabeth Mungard til Hans Hoeg, dateret 25.1. 1983 og til Thomas Steensen, dateret 19.1.1983.

42. Hoeg 1985, s. 25-27: Brev fra Jens Mungard til Hermann Schmidt.

43. Dette afsnit er baseret på: SchleswigHolsteinisches Landesarchiv, Abt. 761, Nr. 24107 og Abt. 357.1, Nr. 208. Martin Sadek skal have en meget stor tak for henvisningen til disse kilder.

44. Steensen 2007, s. 262.

45. Oversat efter Wilts 2010, note 6, der har oversat den frisiske tekst til tysk, hvorfra jeg har oversat den til dansk.

46. Kopier af div. anholdelsesdokumenter findes i DCB, arkiv nr. A1138.

47. Beregnet ud fra Danmarks Statistiks omregner på wwww.dst.dk.

48. DCB, arkiv nr. A1719, brev fra Elisabeth Mungard til Thomas Steensen, dateret 19.1.1983.

49. Hermann Schmidt var udgiver af tidsskriftet Fuar Söl'ring Lir, mens Carl Meyer var forlægger i Westerland på Sild, se ovenfor. 
50. Hoeg 1985, s. 25-27.

51. Oversat efter Wilts 2010, note 1. Oversat med hjælp af Marie Tångeberg.

52. Dermed mener han den nationalsocialistiske stat.

53. Oversat efter Wilts 2010, note 2. Oversat med hjælp af Marie Tångeberg.

54. Oversat efter Wilts 2010, note $10 \mathrm{og}$ note 12. Oversat med hjælp af Marie Tångeberg.

55. Oversat efter Wilts 2010, note 17. Oversat med hjælp af Marie Tångeberg. Overskriften kan også oversættes til »Folkens «.

56. Wilts 2010, s. 25.

57. Kopier af div. arrestdokumenter findes i DCB, arkiv nr. A1138, ligesom der er kopier af Jens Mungards brev til Elisabeth Mungard 1.8.1937.

58. Wilts 1985, s. 43. Oversat med hjælp af Marie Tångeberg.

59. DCB, arkiv nr. A1138.
60. Sadek 2012.

61. Dette afsnit er baseret på LSH, Abt. 357.1, nr. 208 og Abt. 761, nr. 24107.

62. DCB, arkiv nr. A1719: Brev dateret 21.4.1987 fra Karl Schmidt til Friedrich W. Cornelisen, Lorenz Mungard og Willy Schröder.

63. Ibid.

64. Peters 1949, s. 159.

65. Nordfriisk Instituut blev etableret i 1948.

66. Citeret efter Slesvigland 1985, s. 107.

67. Hoeg 1995, forordet.

68. Schmidt 1989.

69. Slesvigland 1985, s. 109.

70. Wilts 1985 og 2010.

71. Wilts 2010, s. 21.

72. DCB, arkiv nr. A1719, brev fra Elisabeth Mungard til Hans Hoeg, dateret 25.1.1983.

73. Digtet er bragt som prolog i Hoeg 1985, s. 8. Oversat med hjælp af Marie Tångeberg.

\section{Zusammenfassung}

Im Februar 1940 starb der friesische Dichter Jens Emil Mungaard im Konzentrationslager Sachsenhausen. Das bedeutete den Abschluss eines beschwerlichen Lebens. Er wurde 1885 in Kejtum auf Sylt geboren als Sohn des bekannten Landwirts und Sprachenforschers Nann Mungaard. Die beiden hatten ein kompliziertes Verhältnis zueinander. Er übernahm gedrungener maßen den Familienhof in Kejtum, der 1921 niederbrannte, nachdem der Vater im Jahr zuvor am Abstimmungskampf teilgenommen hatte, um die Bevölkerung der Insel dazu zu bewegen, ihre Stimme zugunsten der Dänen abzugeben. Das wurde ihm von den deutschgesinnten Friesen auf Sylt übelgenommen, die Fam. Mungaard wurde zunehmend als Außenseiter auf der Insel betrachtet, Jens Mungaard sei zänkisch und streitsüchtig. Im Laufe der zwanziger und dreißiger Jahre ging es für ihn bergab, mehrmals wurde er wegen Diebstahls verurteilt. Nach der nationalsozialistischen Machtübernahme 1933 kam es zu häufigen Unstimmig- 
keiten, Mungaard schrieb kritische Gedichte, die aber erst lange nach Abschluss des Krieges veröffentlicht wurden. Er war der Verfasser von mehr als 800 poetischen Gedichten auf friesischem Dialekt, Sölring; heute gilt er bei vielen als der bedeutendste nordfriesische Dichter. 